\title{
Influence of trace elements supplementation on the production of recombinant frutalin by Pichia pastoris KM71H in fed-batch process
}

\author{
a,b,c Marcela S. O. Wanderley, d Carla Oliveira, a,b,c Danyelly Bruneska, d Lucília \\ Domingues, ${ }^{\mathrm{b}, \mathrm{c}}$ José L. Lima Filho, ${ }^{\mathrm{d}}$ José A. Teixeira, ${ }^{\mathrm{d}}$ Solange I. Mussatto*
}

\author{
${ }^{\mathrm{a}}$ Molecular Prospection and Bioinformatics Group (ProspecMol), ${ }^{\mathrm{b}}$ Laboratory of Immunopathology Keizo Asami, ${ }^{\mathrm{c}}$ Centre of \\ Biological Science, Universidade Federal de Pernambuco, 50670-901 Recife, Brazil \\ ${ }^{\mathrm{d}}$ Institute for Biotechnology and Bioengineering, Centre of Biological Engineering, University of Minho, \\ 4710-057 Braga, Portugal
}

Received 26 October 2012; Revised 15 December 2012; Accepted 31 December 2012

\begin{abstract}
Frutalin, a galactose-specific lectin used to detect specific tumour markers, is a protein with low expression level in breadfruit. In the present study, fed-batch fermentation in a stirred tank bioreactor was used as a strategy to enhance protein production by a recombinant Pichia pastoris $\mathrm{KM} 71 \mathrm{H}$. By using this process, the production of recombinant frutalin was 4-fold higher than the value obtained in shaker flasks batch assays. Supplementation of the fermentation medium with trace elements (Pichia trace minerals, PTM) was also evaluated in order to stimulate production of the recombinant protein. The addition of PTM to the minimum medium afforded a recombinant protein production of $13.4 \mathrm{mg} \mathrm{L}^{-1}$, which was 2.5 -fold higher than that achieved from the culture medium without PTM supplementation. These results are significant as the development of strategies to improve the production of recombinant frutalin may broaden its application in cancer diagnosis.

(C) 2013 Institute of Chemistry, Slovak Academy of Sciences
\end{abstract}

Keywords: Pichia pastoris, fed-batch process, frutalin, lectin, trace elements

\section{Introduction}

Lectins are proteins found in all life forms ranging from viruses, fungi, and bacteria, to animals and plants (Lannoo et al., 2007). These proteins are able to bind reversibly to mono- or oligosaccharides (Peumans et al., 1998) and are related to biological recognition phenomena, mainly cell recognition, interaction, and adhesion (Peumans \& Van Damme, 1998). Frutalin is a homotetrameric $\alpha$-D-galactose lectin belonging to the jacalin family, isolated from Artocarpus incisa. Functionally, this lectin is a potent lymphocyte stimulator (Rahman et al., 2002) capable of inducing chemotaxis and the rearrangement of actin cytoskeleton in human neutrophils, and it has been used successfully as a cancer diagnostic tool (Brando-Lima et al., 2005). However, the use of frutalin isolated from its natural sources presents several disadvantages such as heterogeneity of the sample due to the presence of lectin isoforms, which may lead to variability in the results (Brando-Lima et al., 2006).

The expression of lectin in a heterologous system is an interesting way to overcome this problem, which affords protein samples with high purity. The methylotrophic yeast Pichia pastoris is a highly effective and versatile system for the expression of heterologous proteins (Macauley-Patrick et al., 2005) and has been successfully used for the expression of lectin from lower organisms such as Aleuria aurantia (Amano et al., 2003) and Pleurotus cornucopiae (Sumisa et al., 2004), as well as from plants such as Phaseolus vulgaris agglutinin (PHA), Galanthus nivalis agglutinin (GNA)

\footnotetext{
*Corresponding author, e-mail: solange@deb.uminho.pt, solangemussatto@hotmail.com
} 
(Raemaekers et al., 1999), and Canavalia brasiliensis (ConBr) (Bezerra et al., 2006). Synthetic frutalin was also cloned and expressed in $P$. pastoris under batch conditions (Oliveira et al., 2008).

The production of recombinant protein by fedbatch fermentation is considered more advantageous than the production by batch cultivations, since the toxic effect of the methanol induction is reduced, the production of protein without biomass gain is increased, and it is possible to express extracellular protein with a low quantity of homologous proteins (Taherzadeh et al., 2002). In addition, supplementation of the medium with trace elements (Pichia trace minerals, PTM) during the fed-batch process is reported to increase the production of heterologous proteins (Boze et al., 2001). Given the above, the present work sought to evaluate a fed-batch fermentation process with PTM supplementation as a strategy to increase the production of synthetic frutalin by $P$. pastoris $\mathrm{KM} 71 \mathrm{H}$.

\section{Experimental}

\section{Yeast culture media}

Previously constructed Pichia pastoris KM71H/ pPICZ $\alpha \mathrm{A} /$ recombinant frutalin (Oliveira et al., 2008) was grown in YPD (1\% yeast extract, $2 \%$ peptone, and $2 \%$ dextrose) or BMGH (0.1 M potassium phosphate, $4 \times 10^{-5} \%$ biotin, $1.34 \%$ yeast nitrogen base (YNB), and $1 \%$ glycerol; pH 6.0) media. The solution of trace elements (PTM) was composed of $1.0 \mathrm{~g} \mathrm{~L}^{-1}$ $\mathrm{FeSO}_{4} \cdot 7 \mathrm{H}_{2} \mathrm{O}, 0.005 \mathrm{~g} \mathrm{~L}^{-1} \mathrm{CuSO}_{4} \cdot 5 \mathrm{H}_{2} \mathrm{O}, 0.01 \mathrm{~g} \mathrm{~L}^{-1}$ $\mathrm{H}_{3} \mathrm{BO}_{3}, 0.01 \mathrm{~g} \mathrm{~L}^{-1} \mathrm{MnSO}_{4} \cdot \mathrm{H}_{2} \mathrm{O}, 0.07 \mathrm{~g} \mathrm{~L}^{-1} \mathrm{ZnSO}_{4}$. $7 \mathrm{H}_{2} \mathrm{O}$, and $0.01 \mathrm{~g} \mathrm{~L}^{-1} \mathrm{Na}_{2} \mathrm{MoO}_{4} \cdot 2 \mathrm{H}_{2} \mathrm{O}$. All the solutions were autoclaved at $121^{\circ} \mathrm{C}$ for $20 \mathrm{~min}$, or sterilised by filtration through $0.22 \mu \mathrm{m}$ filters (Millipore ${ }^{\circledR}$, France) prior to use.

All chemicals were purchased from Sigma-Aldrich (USA) or from Merck (Germany) and used without further purification.

\section{Fed-batch fermentation}

Fermentation assays were carried out in fed-batch mode in a $1.6 \mathrm{~L}$ stirred tank bioreactor (Autoclavable Benchtop Fermenter Type R'ALF, Bioengineering AG, Switzerland) containing $1 \mathrm{~L}$ of fermentation medium (working volume). The vessel was jacketed and the water temperature was maintained at $30^{\circ} \mathrm{C}$. During the fermentations, the $\mathrm{pH}$ was maintained at 5.0 by using a $1.0 \mathrm{M} \mathrm{NaOH}$ solution, and $100 \mu \mathrm{L}$ of anti-foaming agent (Antifoam A, SigmaAldrich) was added to the culture medium. The dissolved oxygen (DO) level was maintained at over $30 \%$ of air saturation by a cascaded control of agitation (320-550 $\left.\mathrm{min}^{-1}\right)$ and aeration rate $\left(3-5 \mathrm{~L} \mathrm{~min}^{-1}\right)$. The temperature, DO, pH, agitation, aeration, anti- foam, and carbon source were monitored throughout the fermentation period.

The fed-batch fermentation process consisted of three phases: (i) an initial glycerol batch to promote the cell growth; (ii) a glycerol fed-batch for the alcohol oxidase derepression and to obtain high cell density; (iii) an induction phase for expression of the recombinant frutalin. In the first step, $P$. pastoris $\mathrm{KM} 71 \mathrm{H}$ was grown in a BMGH medium $(1 \mathrm{~L})$ over $24 \mathrm{~h}$. After this period, the glycerol fed-batch phase started, being the feed medium $(30 \mathrm{~mL}$ of $50 \mathrm{vol}$. $\%$ glycerol solution whether or not supplemented with $12 \mathrm{~mL} \mathrm{~L}^{-1}$ trace metal solution) fed at a flow-rate of $1.5 \mathrm{~mL} \mathrm{~h}^{-1} \mathrm{~L}^{-1}$ or $6.0 \mathrm{~mL} \mathrm{~h}^{-1} \mathrm{~L}^{-1}$. In the induction phase, methanol, whether or not supplemented with $12 \mathrm{~mL} \mathrm{~L}^{-1}$ of a trace metal solution, was added to the medium at a flow-rate of $6 \mathrm{~mL} \mathrm{~min}^{-1}$. In this phase, the temperature was maintained at $28^{\circ} \mathrm{C}$.

Assays in shaker flasks were carried out for expression on a small-scale. In these assays, a single colony of the microorganism was inoculated into $50 \mathrm{~mL}$ of BMGH medium and maintained at $30^{\circ} \mathrm{C}, 250 \mathrm{~min}^{-1}$, for $24 \mathrm{~h}$. Next, the cells were harvested by centrifugation $\left(3000 \mathrm{~g}, 4^{\circ} \mathrm{C}, 15 \mathrm{~min}\right)$ and re-suspended to an optical density (OD 600) of 1.0 in BMMH (0.1 M potassium phosphate, $4 \times 10^{-5} \%$ biotin, $13.4 \% \mathrm{YNB}$, and $0.1 \%$ methanol; pH 6.0) medium whether or not supplemented with $12 \mathrm{~mL} \mathrm{~L}^{-1}$ of a trace metal solution to induce expression. To overcome lack of oxygen, induction was carried out in $500 \mathrm{~mL}$ baffled flasks filled with $50 \mathrm{~mL}$ of culture medium and covered with two layers of sterile gauze. Every $24 \mathrm{~h}$, methanol was added to the medium (to afford a final methanol concentration of 1.0 vol. \%) to maintain induction. The induction phase occurred over $96 \mathrm{~h}$, at $28^{\circ} \mathrm{C}$.

\section{Analytical methods}

Cell concentration (dry mass per volume) was determined by measuring the optical density (OD) of the yeast culture samples at $600 \mathrm{~nm}$, which was correlated to a calibration curve (dry mass $\times$ OD). Glycerol and methanol concentrations were measured by high-performance liquid chromatography (HPLC) in a Jasco chromatograph (Japan) equipped with a refractive index detector and a Bio-Rad Aminex HPX$87 \mathrm{H}$ column $(300 \mathrm{~mm} \times 7.8 \mathrm{~mm})$ at $60^{\circ} \mathrm{C}$, using $0.005 \mathrm{M}$ sulphuric acid as eluent at a flow-rate of $0.7 \mathrm{~mL} \mathrm{~min}^{-1}$. The total protein concentration in the samples was determined by the Bradford protein assay using bovine serum albumin (Sigma-Aldrich) as the concentration standard. The production of recombinant frutalin was analysed by SDS-PAGE using a $12 \%$ gel stained with Coomassie brilliant blue (Sigma-Aldrich), as previously described (Laemmli, 1970). All the analytical determinations were performed in triplicate. 


\section{Recombinant protein purification}

The supernatants from fed-batch fermentations were separated from the yeast cells by centrifugation $\left(3000 \mathrm{~g}, 4^{\circ} \mathrm{C}, 10 \mathrm{~min}\right)$. Salts were precipitated by the $\mathrm{pH}$ increase to 7.5 by adding $10 \mathrm{~N} \mathrm{NaOH}$, and removed by centrifugation $\left(3000 \mathrm{~g}, 4^{\circ} \mathrm{C}, 10 \mathrm{~min}\right)$. Next, the supernatants were filtered through $0.22 \mu \mathrm{m}$ pore size filters, concentrated and washed with $\mathrm{PBS}$ buffer $\left(8.00 \mathrm{~g} \mathrm{~L}^{-1} \mathrm{NaCl}, 0.20 \mathrm{~g} \mathrm{~L}^{-1} \mathrm{KCl}, 2.68 \mathrm{~g} \mathrm{~L}^{-1}\right.$ $\mathrm{Na}_{2} \mathrm{HPO}_{4} \cdot 7 \mathrm{H}_{2} \mathrm{O}$, and $\left.0.24 \mathrm{~g} \mathrm{~L}^{-1} \mathrm{KH}_{2} \mathrm{PO}_{4} ; \mathrm{pH} 7.4\right)$ to a final volume of $1-1.5 \mathrm{~mL}$ in $10 \mathrm{kDa}$ Amicon tubes (Millipore, France). The treated supernatants were analysed by SDS-PAGE and FPLC systems (Pharmacia Biotechnology, USA) using a Sephacryl S-100 HR column (HiPrep 16/60, Pharmacia Biotechnology), previously washed with distilled water and equilibrated with PBS buffer at a flow-rate of $1 \mathrm{~mL} \mathrm{~min}^{-1}$. The purity of the frutalin was confirmed by SDSPAGE followed by silver nitrate staining. The concentration of pure recombinant was determined by measuring the OD at $280 \mathrm{~nm}$.

\section{Haemagglutination assays}

Samples of the recombinant frutalin were prepared by serial dilutions $\left(\varphi_{\mathrm{r}}=1: 2\right)$ from a starting $\left(\varphi_{\mathrm{r}}=\right.$ $1: 1)$ medium up to $\left(\varphi_{\mathrm{r}}=1: 128\right)$, and $100 \mu \mathrm{L}$ was incubated with $100 \mu \mathrm{L}$ of rabbit erythrocytes (2 vol. \% in $0.15 \mathrm{M} \mathrm{NaCl}$ ) at $37^{\circ} \mathrm{C}$ for $30 \mathrm{~min}$ (Oliveira et al., 2008). The degree of agglutination was visually monitored after the tubes had been left at $37^{\circ} \mathrm{C}$ for $30 \mathrm{~min}$ followed by another $30 \mathrm{~min}$ at ambient temperature. Samples yielding no visible agglutination activity after these incubation steps were regarded as negative. Native frutalin was used as a positive control, exhibiting agglutination activity.

\section{Results and discussion}

\section{Production of recombinant frutalin by fed- batch fermentation}

Recombinant $P$. pastoris $\mathrm{KM} 71 \mathrm{H}$ was grown in a minimal medium containing glycerol. After exhaustion of the glycerol from the medium, frutalin production was induced by the addition of $0.8 \%$ methanol, which also acted as a carbon source for P. pastoris during the fermentation (Cereghino \& Cregg, 2000). By using this fed-batch process, a biomass production of $122.3 \mathrm{~g} \mathrm{~L}^{-1}$ and a final concentration of pure frutalin of $5.23 \mathrm{mg} \mathrm{L}^{-1}$ were obtained. This frutalin concentration is higher than that achieved in Erlenmeyer flasks $\left(2.1 \mathrm{mg} \mathrm{L}^{-1}\right)$. In effect, the levels of protein obtained in shaker flasks experiments are generally lower than those obtained in bioreactors, because the cell density is lower and the aeration is often limited (Daly \& Hearn, 2005). However, the values ob- tained in the present work are lower than others reported for recombinant lectins expressed in $P$. pastoris in shaker flasks (fruiting-body lectins of Pleurotus cornucopiae (60 $\mathrm{mg} \mathrm{L}^{-1}$ ) (Iijima et al., 2003) and N. tabacum lectin (6 mg L $\left.{ }^{-1}\right)$ (Lannoo et al., 2007)) and in fed-batch experiments (Amaryllidaceae snowdrop agglutinin $\left(80.0 \mathrm{mg} \mathrm{L}^{-1}\right)$ (Baumgartner et al., 2003) and Phaseolus vulgaris phytohemagglutinin Eform (100 $\mathrm{mg} \mathrm{L}^{-1}$ ) (Baumgartner et al., 2002)), suggesting that the system used in the present work was not efficient enough to produce high levels of frutalin.

The recombinant frutalin produced exhibited an SDS-PAGE migration pattern very similar to that of the native frutalin (Fig. 1b). The upper band in the SDS-PAGE gel indicates that the recombinant frutalin has been glycosylated by $P$. pastoris KM71H. As expected, the recombinant frutalin did not present haemagglutinating activity towards rabbit erythrocytes. This result has been attributed to the glycosylation pattern of $P$. pastoris and has also been observed for another fruiting-body lectin (Iijima et al., 2003).

\section{Influence of PTM supplementation on frutalin production}

During the phase to obtain high cell density, the cells may experience a limitation of basal salts, which may prevent use of the carbon source. As a result, some studies report the need for nutrients supplementation during the feed and induction phases of the fedbatch process (Hang et al., 2009; Arnau et al., 2010; Khongto et al., 2011). PTM supplementation satisfies the nutritional requirements of the cells during the nutrients starvation period (Xiao et al., 2006). In the present study, assays in shaker flasks and in the fedbatch bioreactor were performed seeking to verify the influence of the medium supplementation with PTM on frutalin production. As can be seen in Fig. 1a, cell growth was similar in the media supplemented with or without PTM, so differences were not observed in the specific growth rate ( $\mu$, Table 1$)$. Although supplementation of the medium with PTM has been reported to overcome the basal salts limitation by yeast cell, and to reverberate in biomass production (Chauhan et al., 1999; Hang et al., 2009; Arnau et al., 2010), it had no significant influence on the cell growth of $P$. pastoris KM71H (present study). Similar results for the fermentation medium supplementation with trace elements on cell growth have been reported (Chauhan et al., 1999).

The addition of PTM (12 $\left.\mathrm{mL} \mathrm{L}^{-1}\right)$ during the methanol feed resulted in an increase in the levels of recombinant frutalin compared with the levels obtained by induction in the absence of supplementation (Table 1). By supplementing the cultivation medium with PTM, P. pastoris was able to produce $13.4 \mathrm{mg} \mathrm{L}{ }^{-1}$ of recombinant frutalin, which is 2.5-fold higher than that obtained in the absence 
Table 1. Biomass production, recombinant frutalin concentration and specific growth rate $(\mu)$ obtained during fed-batch fermentation with Pichia pastoris KM71H in stirred tank bioreactor

\begin{tabular}{|c|c|c|c|}
\hline \multirow{2}{*}{ Induction conditions } & Dry mass & $\mu^{a}$ & Pure recombinant frutalin \\
\hline & $\mathrm{g} \mathrm{L}^{-1}$ & $\mathrm{~h}^{-1}$ & $\mathrm{mg} \mathrm{L}^{-1}$ \\
\hline PTM supplementation & 124.1 & 0.060 & 13.40 \\
\hline Without PTM supplementation & 122.3 & 0.059 & 5.23 \\
\hline
\end{tabular}

a) Calculated by linear regression of specific growth rate observed during glycerol feeding.

a

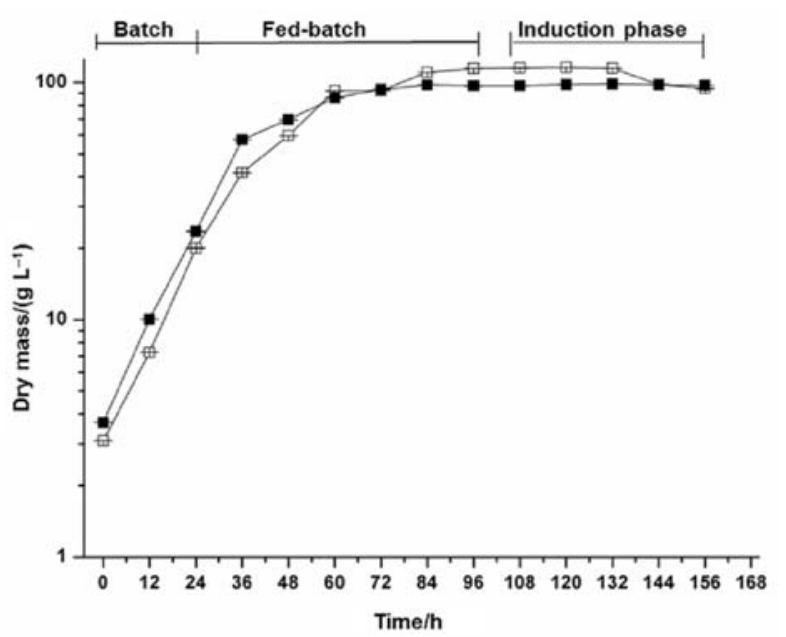

b

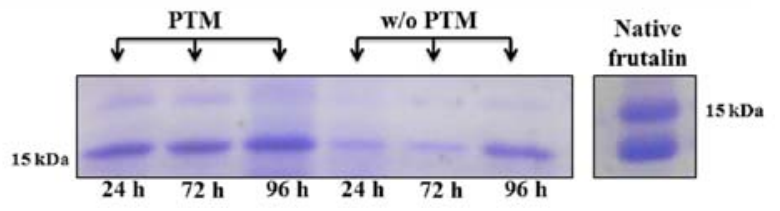

Fig. 1. Fed-batch process for production of recombinant frutalin by Pichia pastoris KM71H. Comparative profile of yeast growth in medium supplemented with PTM (ם) or without PTM (ם), and time course of batch, fed-batch and induction phases (a), recombinant frutalin migration in SDS-PAGE gel followed by Coomassie brilliant blue staining at $24 \mathrm{~h}, 72 \mathrm{~h}$, and $96 \mathrm{~h}$ after onset of growth, and influence of PTM supplementation on recombinant frutalin production (b).

of PTM. In shaker-flasks, the frutalin production achieved $3.3 \mathrm{mg} \mathrm{L} \mathrm{L}^{-1}$, representing a 1.5 -fold increase over the non-supplemented assays. Some studies also reported an increase in the production of other recombinant proteins by $P$. pastoris, including hepatitis B virus surface antigen ( $\mathrm{HBsAg})$, phytase, angiostatin, and alpha-amylase, after supplementation of the medium with trace elements during the fed-batch process (Chauhan et al., 1999; Lee et al., 2003; Chen et al., 2004; Xie et al., 2005).

The cultivation of $P$. pastoris on defined media is associated with a high rate of protease expression, es-

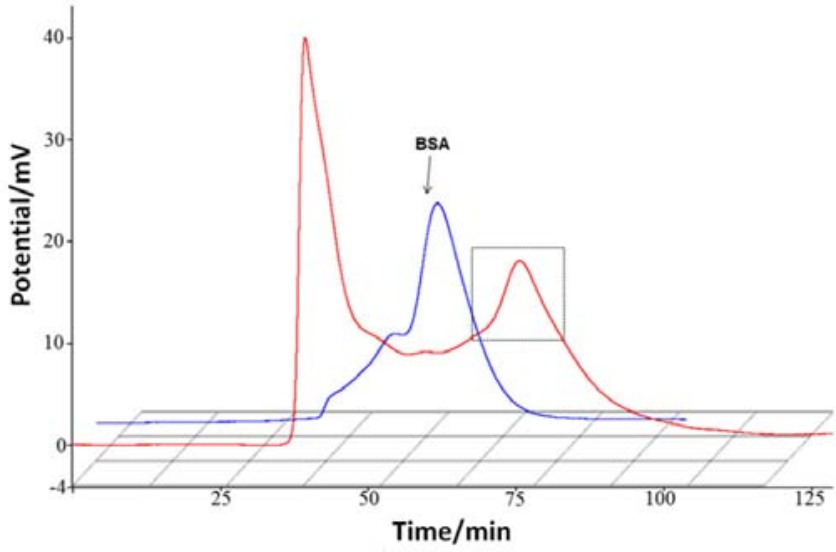

Fig. 2. Elution profile of fed-batch process supernatant on Sephacryl ${ }^{\circledR}$ S-100HR column.

pecially in high cell density cultures. In defined media, the nitrogen depletion results in an increase in the protease activity, which can be avoided by increasing the initial nitrogen concentration or by supplementing the medium with it. Nutrient starvation leads to autophagic cell degradation and lyses, leading to the release of vacuolar proteases (Todde et al., 2009). The use of PTM increases the protein production by increasing the cell viability as well as by improving the final protein concentration due to the strong decrease in the proteolytic degradation of recombinant proteins (Chauhan et al., 1999; Boze et al., 2001; Xiao et al., 2006; Ghosalkar et al., 2008; Roepcke et al., 2011). Moreover, the stability of the recombinant protein is further enhanced by the addition of PTM to the culture medium, possibly by acting as alternative and competing substrates for one or more proteases. These supplements can also repress protease induction caused by nutrients limitation (Macauley-Patrick et al., 2005).

Analysis by SDS-PAGE revealed the recombinant frutalin produced by $P$. pastoris $\mathrm{KM} 71 \mathrm{H}$ after $24 \mathrm{~h}$, $72 \mathrm{~h}$, and $96 \mathrm{~h}$ of methanol induction (Fig. 1b). As can be seen, the production of recombinant frutalin increased with the increase in induction time, both in the presence and in the absence of PTM. Furthermore, the production is higher in the presence of PTM, showing the positive effect of the supplementation on the production of recombinant frutalin. This also corrobo- 
rates the levels of recombinant frutalin production referred to above. The size-exclusion chromatogram in Fig. 2 shows the elution profile of the recombinant frutalin during the purification process. The SDS-PAGE analysis followed by silver nitrate staining confirmed the purity of the recombinant frutalin.

\section{Conclusions}

Supplementation of the fermentation medium with PTM during the fed-batch process was demonstrated to be an important and significant strategy to increase the production of recombinant frutalin by Pichia pastoris KM71H. This finding is of great interest since increased production of recombinant frutalin may extend its application in cancer diagnosis and therapy.

Acknowledgements. The authors are grateful for the financial support received from Erasmus Mundus External Cooperation Window - ISAC programme, and Conselho Nacional de Desenvolvimento Cientifico e Tecnológico (CNPQ) - Brazil.

\section{References}

Amano, K., Takase, M., Ando, A., \& Nagata, Y. (2003). Production of functional lectin in Pichia pastoris directed by cloned cDNA from Aleuria aurantia. Bioscience, Biotechnology, and Biochemistry, 67, 2277-2279. DOI: 10.1271/bbb.67.2277.

Arnau, C., Ramon, R., Casas, C., \& Valero, F. (2010). Optimization of the heterologous production of a Rhizopus oryzae lipase in Pichia pastoris system using mixed substrates on controlled fed-batch bioprocess. Enzyme and Microbial Technology, 46, 494-500. DOI: 10.1016/j.enzmictec.2010.01.005.

Baumgartner, P., Raemaekers, R. J. M., Durieux, A., Gatehouse, A., Davies, H., \& Taylor, M. (2002). Large-scale production, purification, and characterisation of recombinant Phaseolus vulgaris phytohemagglutinin E-form expressed in the methylotrophic yeast Pichia pastoris. Protein Expression and Purification, 26, 394-405. DOI: 10.1016/s10465928(02)00555-7.

Baumgartner, P., Harper, K., Raemaekers, R. J. M., Durieux, A., Gatehouse, A. M. R., Davies, H. V., \& Taylor, M. A. (2003). Large-scale production and purification of recombinant Galanthus nivalis agglutinin (GNA) expressed in the methylotrophic yeast Pichia pastoris. Biotechnology Letters, 25, 1281-1285. DOI: 10.1023/a:1025007901322.

Bezerra, W. M., Carvalho, C. P. S., Moreira, R. A., \& Grangeiro, T. B. (2006). Establishment of a heterologous system for the expression of Canavalia brasiliensis lectin: a model for the study of protein splicing. Genetics and Molecular Research, $5,216-223$.

Boze, H., Laborde, C., Chemardin, P., Richard, F., Venturin, C., Combarnous, Y., \& Moulin, G. (2001). High-level secretory production of recombinant porcine follicle-stimulating hormone by Pichia pastoris. Process Biochemistry, 36, 907913. DOI: $10.1016 / \mathrm{s} 0032-9592(00) 00296-x$.

Brando-Lima, A. C., Saldanha-Gama, R. F., Henriques, M. G. M. O., Monteiro-Moreira, A. C. O., Moreira, R. A., \& BarjaFidalgo, C. (2005). Frutalin, a galactose-binding lectin, induces chemotaxis and rearrangement of actin cytoskeleton in human neutrophils: Involvement of tyrosine kinase and phosphoinositide 3-kinase. Toxicology and Applied Pharmacology, 208, 145-154. DOI: 10.1016/j.taap.2005.02.012.

Brando-Lima, A., Saldanha-Gama, R. F., Pereira, C. R., Villela, C. G., Sampaio, A. L. F., Monteiro-Moreira, A. C. O.,
Henriques, M. G. M. O., Moreira, R. A., \& Barja-Fidalgo, C. (2006). Involvement of phosphatidylinositol-3 kinase-Akt and nuclear factor kappa-B pathways in the effect of frutalin on human lymphocyte. International Immunopharmacology, 6, 465-472. DOI: 10.1016/j.intimp.2005.09.008.

Cereghino, J. L., \& Cregg, J. M. (2000). Heterologous protein expression in the methylotrophic yeast Pichia pastoris. FEMS Microbiology Reviews, 24, 45-66. DOI: 10.1111/j. 1574-6976.2000.tb00532.x.

Chauhan, A. K., Arora, D., \& Khanna, N. (1999). A novel feeding strategy for enhanced protein production by fed-batch fermentation in recombinant Pichia pastoris. Process Biochemistry, 34, 139-145. DOI: 10.1016/s0032-9592(98)000806.

Chen, C. C., Wu, P. H., Huang, C. T., \& Cheng, K. J. (2004). A Pichia pastoris fermentation strategy for enhancing the heterologous expression of an Escherichia coli phytase. Enzyme and Microbial Technology, 35, 315-320. DOI: 10.1016/j.enzmictec.2004.05.007.

Daly, R., \& Hearn, M. T. W. (2005). Expression of heterologous proteins in Pichia pastoris: a useful experimental tool in protein engineering and production. Journal of Molecular Recognition, 18, 119-138. DOI: 10.1002/jmr.687.

Ghosalkar, A., Sahai, V., \& Srivastava, A. (2008). Optimization of chemically defined medium for recombinant Pichia pastoris for biomass production. Bioresource Technology, 99, 7906-7910. DOI: 10.1016/j.biortech.2008.01.059.

Hang, H. F., Ye, X. H., Guo, M. J., Chu, J., Zhuang, Y. P., Zhang, M., \& Zhang, S. L. (2009). A simple fermentation strategy for high-level production of recombinant phytase by Pichia pastoris using glucose as the growth substrate. Enzyme and Microbial Technology, 44, 185-188. DOI: 10.1016/j.enzmictec.2008.12.002.

Iijima, N., Amano, K., Ando, A., \& Nagata, Y. (2003). Production of fruiting-body lectins of Pleurotus cornucopiae in methylotrophic yeast Pichia pastoris. Journal of Bioscience and Bioengineering, 95, 416-418. DOI: 10.1016/s1389-1723 (03)80079-8.

Khongto, B., Laoteng, K., \& Tongta, A. (2011). Enhancing the production of gamma-linolenic acid in Hansenula polymorpha by fed-batch fermentation using response surface methodology. Chemical Papers, 65, 124-131. DOI: 10.2478/s11696-010-0099-2.

Laemmli, U. K. (1970). Cleavage of structural proteins during the assembly of the head of bacteriophage T4. Nature, 227, 680-685. DOI: $10.1038 / 227680 \mathrm{a} 0$.

Lannoo, N., Vervecken, W., Proost, P., Rougé, P., \& Van Damme, E. J. M. (2007). Expression of the nucleocytoplasmic tobacco lectin in the yeast Pichia pastoris. Protein Expression and Purification, 53, 275-282. DOI: 10.1016/j.pep.2007.01.007.

Lee, C. Y., Nakano, A., Shiomi, N., Lee, E. K., \& Katoh, S. (2003). Effects of substrate feed rates on heterologous protein expression by Pichia pastoris in DO-stat fed-batch fermentation. Enzyme and Microbial Technology, 33, 358-365. DOI: 10.1016/s0141-0229(03)00146-7.

Macauley-Patrick, S., Fazenda, M. L., McNeil, B., \& Harvey, L. M. (2005). Heterologous protein production using the Pichia pastoris expression system. Yeast, 22, 249-270. DOI: 10.1002/yea.1208.

Oliveira, C., Felix, W., Moreira, R. A., Teixeira, J. A., \& Domingues, L. (2008). Expression of frutalin, an $\alpha$-Dgalactose-binding jacalin-related lectin, in the yeast Pichia pastoris. Protein Expression and Purification, 60, 188-193. DOI: $10.1016 /$ j.pep.2008.04.008.

Peumans, W. J., \& Van Damme, E. J. (1998). Plant lectins: specific tools for the identification, isolation, and characteri- 
zation of O-linked glycans. Critical Reviews in Biochemistry and Molecular Biology, 33, 209-258.

Peumans, W. J., Roy, S., Barre, A., Rouge, P., van Leuven, F., \& van Damme, E. J. M. (1998). Elderberry (Sambucus nigra) contains truncated Neu5Ac $(\alpha-2,6) \mathrm{Gal} / \mathrm{GalNAc}$-binding type 2 ribosome-inactivating proteins. FEBS Letters, 425, 35-39. DOI: 10.1016/s0014-5793(98)00193-8.

Raemaekers, R. J. M., de Muro, L., Gatehouse, J. A., \& Fordham-Skelton, A. P. (1999). Functional phytohemagglutinin (PHA) and Galanthus nivalis agglutinin (GNA) expressed in Pichia pastoris. European Journal of Biochemistry, 265, 394-403. DOI: 10.1046/j.1432-1327.1999.00749.x.

Rahman, M. A., Karsani, S. A., Othman, I., Rahman, P. S. A., \& Hashim, O. H. (2002). Galactose-binding lectin from the seeds of champedak (Artocarpus integer): sequences of its subunits and interactions with human serum O-glycosylated glycoproteins. Biochemical and Biophysical Research Communications, 295, 1007-1013. DOI: 10.1016/s0006-291x(02) 00795-7.

Roepcke, C. B. S., Vandenberghe, L. P. S., \& Soccol, C. R. (2011). Optimized production of Pichia guilliermondii biomass with zinc accumulation by fermentation. Animal Feed Science and Technology, 163, 33-42. DOI: 10.1016/j. anifeedsci.2010.09.018.
Sumisa, F., Iijima, N., Ando, A., Shiga, M., Kondo, K., Amano, K., \& Nagata, Y. (2004). Properties of mycelial aggregatespecific lectin of Pleurotus cornucopiae produced in Pichia pastoris. Bioscience, Biotechnology, and Biochemistry, 68, 959-960. DOI: 10.1271/bbb.68.959.

Taherzadeh, M. J., Adler, L., \& Lidén, G. (2002). Strategies for enhancing fermentative production of glycerol-a review. Enzyme and Microbial Technology, 31, 53-66. DOI: 10.1016/s0141-0229(02)00069-8.

Todde, V., Veenhuis, M., \& van der Klei, I. J. (2009). Autophagy: principles and significance in health and disease. Biochimica et Biophysica Acta (BBA) - Molecular Basis of Disease, 1792, 3-13. DOI: 10.1016/j.bbadis.2008.10.016.

Xiao, A. F., Zhou, X. S., Zhou, L., \& Zhang, Y. X. (2006). Improvement of cell viability and hirudin production by ascorbic acid in Pichia pastoris fermentation. Applied Microbiology and Biotechnology, 72, 837-844. DOI: 10.1007/s00253-0060338-1.

Xie, J. L., Zhou, Q. W., Du, P., Gan, R. B., \& Ye, Q. (2005). Use of different carbon sources in cultivation of recombinant Pichia pastoris for angiostatin production. Enzyme and Microbial Technology, 36, 210-216. DOI: 10.1016/j.enzmictec.2004.06.010. 